\title{
Ст атьи
}

Пространственная Экономика

2005. № 1. C. 27-45

УДК 911.63(571.6)

П. Я. Бак^анов, В. П. Каракин, А. С. Шейнгауз

ПРИРОАОПОАЬЗОВАНИЕ

$\triangle$ ААЬНЕГО ВОСТОКА РОССИИ

И СОПРЕАЕАЬНЫХ ТЕРРИТОРИЙ

Природопользование является самым пространственным видом деятельности, его структурно-функциональная модель включает социальные, экологические и экономические аспекты. Предложена классификация типов пространственной структуры природопользования. На примере российского Дальнего Востока показаны пространственные закономерности регионального природопользования в рамках макроэкономического районирования.

Пространственная структура природопользования, классификация типов, дальневосточное природопользование.

В настоящей статье авторы рассматривают природопользование в соответствии со своими ранее сформулированными подходами $[2 ; 5 ; 7 ; 9 ; 12]$ как практическую деятельность человека с его различным техническим вооружением, которая:

- базируется на непосредственном использовании всего комплекса различных природных ресурсов и условий территориальных природных комплексов и одновременно воздействует на них;

- заключается не только в вовлечении этих ресурсов и условий в социальную сферу и/или экономически эффективное производство, но предусматривает их обязательное восстановление, в случае их восстановимости, и преобразование, в случае общественно оправданной необходимости;

- обеспечивает обществу и отдельным его группам и индивидуумам полу-

(C) Бакланов П. Я., Каракин В. П., Шейнгауз А. С., 2005

Исследование проведено при поддержке Российского фонда фундаментальных исследований, грант № 04-06-97011. 
чение разнообразных продуктов и услуг на основании освоения вещественных и невещественных полезностей природных ресурсов.

Авторы рассматривают природопользование также как научную дисциплину, изучающую эту практическую деятельность в прикладном и теоретическом аспектах [14].

С философско-методологической позиции природопользование - это основа механизма коэволюции природы и общества. С позиции человеческого измерения негативная особенность этой коэволюции заключается в том, что нет какой-то жесткой предопределенности успешного перехода природопользования к устойчивому развитию и созданию ноосферы. Для успешного движения в этом направлении необходимо многое, но для научного обеспечения перехода к устойчивому развитию требуется, в первую очередь, методологическое осознание связанности экономических, экологических и социально-культурологических аспектов развития территорий/акваторий в рамках общего процесса природопользования.

Это выдвигает природопользование в ряд важнейших инструментов управления развитием пространства и одновременно в ряд важнейших объектов управления. Природопользование как инструмент и как объект представлено на всех таксономических уровнях территории/акватории, от конкретного объекта (ферма, шахта, лесосека и т. д.) до планеты Земля в целом. Роль природопользования как стержневого процесса освоения территории/акватории и как эффективного объекта управления пространством, с нашей точки зрения, сегодня не до конца осознана ни государственной практикой управления, ни наукой. Государственное управление рассматривает природопользование как набор экономических проблем, отягощенных социально-экологическими ограничениями. Подход науки к природопользованию также сводится преимущественно к рассмотрению его в качестве области сугубо прикладных ресурсных исследований.

Природопользование как многогранное явление всегда исходно неоднородно в своем пространственном распределении, т. к.:

- неразрывно постоянное взаимное переплетение всех видов ресурсов между собой и с пространством;

- неоднородно размещение природных ресурсов - земельных и лесных массивов, водных ресурсов, стад рыб и животных, месторождений полезных ископаемых, красивых ландшафтов и т. д.;

- различна степень экономической освоенности территорий/акваторий, в пределах которых осуществляется природопользование, а это определяет степень экономической доступности/недоступности ресурсов и уровни их использования;

- различна изученность территорий/акваторий, а, следовательно, не приведены в полную известность все ресурсы; и не завершена еще реализация пер- 
вой стадии природопользования в виде земле- и лесоустройства, геологоразведки. В этой связи можно полагать, что на любой территории/акватории все имеющиеся в ее пределах ресурсы не приведены в полную известность;

- различны физико-географические условия разных участков, что определяет не только физическую, но и экономическую доступность/недоступность ресурсов на этих участках.

Пространственная неоднородность всех перечисленных факторов и природопользования в целом усиливается по мере увеличения размеров рассматриваемой территории, перехода от более мелкого территориального/акваториального таксона к более крупному.

Еще один важный принцип, лежащий в основе пространственного анализа природопользования, - социально-эколого-экономическая многоаспектность структурно-функциональной модели системы природопользования вообще и Дальнего Востока России (ДВР) в частности. Осуществление природопользования это пространство трансформирует, может усилить дифференциацию, а может нивелировать ее.

Природопользование имеет с пространством не только прямое, но и обратное взаимодействие. То есть оно не только зависит от физических и хозяйственных характеристик пространства, но и изменяет эти характеристики, сокращая или, наоборот, обогащая ресурсный, а также всякий другой потенциал и перестраивая характер ландшафтов:

- микро- и даже мезорельеф;

- внутреннюю и внешнюю структуру растительного покрова, в том числе омолаживает и деконцентрирует лесной покров, создает искусственные лесные ландшафты за пределами лесной зоны;

- видовой состав и размещение дикого животного мира;

- характер поверхностного стока и гигрографа;

- температуру и мутность континентальных и морских вод и т. д.

Это связано с тем, что природно-ресурсные компоненты - это одновременно и компоненты природных систем. В то же время природопользование изменяет и многие социально-экономические компоненты территории, например, транспортную инфраструктуру, размещение хозяйственных объектов, систему поселений и пр.

Причем большинство этих проявлений происходит спонтанно, на основе своих внутренних, еще далеко не познанных закономерностей, т. е. внепланово, несмотря на современные возможности предварительного моделирования последствий освоения того или иного природного объекта.

Еще одна особенность природопользования - его непрерывное «движение» по территории/акватории в качестве составляющей освоения и регионального развития. 
Общепризнанная сейчас необходимость устойчивости природопользования как составной части устойчивости развития может быть реализована лишь при значительных пространственных размерах объектов реализации. Освоение объектов небольшого пространственного размера, отражаемых в виде точки на картах даже крупного масштаба, как правило, происходит по одной и той же классической схеме смены фаз: создание мощностей освоения - наращивание объемов освоения - равномерное использование - снижение уровня использования из-за постепенного истощения ресурсов - прекращение использования из-за исчерпания объекта. При этом и истощение, и исчерпание могут быть не полными, а условными, связанными только с технологическими и экономическими возможностями в данном временном периоде. Изменение этих возможностей может позволить вернуться к освоению объекта в новом варианте.

В целом такая постоянная смена фаз приводит к необходимости переходить от старых к новым объектам - «продвигаться». Это движение является основой экспансии освоения пространства, смены ареалов освоения, их расширения, сокращения, процветания, депрессии и т. д., т. е. динамики структур природопользования в пространстве и времени.

Таким образом, природопользование - наиболее «пространственный» вид экономической деятельности, с которым может быть сравним в этом отношении только транспортный сектор экономики. Оно в значительной степени влияет на изменение экономического пространства, особенно на появление новых центров освоения. Конечно, центры освоения могут появляться и вне природопользования, но и такие центры, как минимум, изменяют структуру земле- или морепользования, а тем самым вовлекаются в воздействие природопользования на пространство.

Именно природопользование закрепляет «пространственность» остальных видов хозяйственной деятельности, т. к. оно всегда формирует базу этих видов деятельности, прежде всего, через свой главный вид пользования - земле- или морепользование, без которых невозможен никакой другой вид природопользования.

Особенно четко это проявляется на региональном уровне. Как показывает опыт хозяйственного освоения любых новых территорий, региональное природопользование осуществляется через воздействия человека с его техническим вооружением на природно-ресурсные системы и сводится в целом к добыче и использованию природных ресурсов и изменению природно-ресурсных и природных систем. При этом любая социально-экономическая составляющая регионального развития: заселение территории, формирование инфраструктурных объектов, размещение производств и т. д. - порождает соответствующее звено природопользования. Все это позволяет сформулировать следующие принципиальные положения регионального природопользования: 
- в любом виде хозяйственной деятельности всегда используется сочетание природных ресурсов: земельных, водных, атмосферных и др.;

- любой вид хозяйственной деятельности всегда осуществляет прямое и обратное ресурсопотребление, т. е. изменение природно-ресурсного потенциала за счет техногенных воздействий и выведения хозяйственных отходов;

- различные звенья природопользования входят во все составляющие регионального развития;

- конкретные звенья регионального природопользования всегда реализуются и имеют строгое пространственное, территориальное/акваториальное, выражение;

- существует определенная взаимодополняемость и пространственно-временная симметрия социально-экономических и природно-ресурсных звеньев в региональном развитии;

- существуют различные формы связанности отдельных природных ресурсов между собой как через природные процессы, так и через процессы хозяйственного освоения территорий;

- наиболее полным объектом оценки природных ресурсов региона, его природно-ресурсного потенциала являются территориальные/акваториальные природно-ресурсные системы;

- любое звено природопользования имеет свое определенное отражение в стоимостной форме, в движении стоимости.

Природопользование всегда вносит свою лепту в стоимость продукта, и нередко она наиболее ценная (хотя бы по абсолютной величине) именно в тех местах, где развит не только первичный, но и вторичный и третичный секторы экономики, т. е. где на единице пространства создается больше продукта. В таких странах/регионах и земля намного дороже, потому что на ней создается больше продукции.

Из всех секторов экономики именно природопользование в наибольшей мере связано с национально-культурологическими проблемами, проблемами национальной культурной самоидентификации, ибо именно тип и метод природопользования либо сохраняют, либо разрушают национальные особенности жизни негородского населения. Ряд стран, например Япония и Республика Корея, в своей политике природопользования в значительной мере исходят из необходимости решения социально-культурологических задач, прежде всего сохранения национальных основ (поддержка сельского и лесного хозяйства, развитие аквакультуры, лоббирование китобойного промысла и т. д.).

В связи с этим управление природопользованием всегда в значительной степени реализует функции управления территорией/акваторией, а неэффективное управление природопользованием приводит к потере контроля над пространством. В то же время природопользование служит инструментом управле- 
ния природной средой, источником значительных воздействий на общество и экономику, особенно в таких все еще осваиваемых регионах, как Сибирь и ДВР.

Но именно природопользование, будучи набором антропогенно-природных систем, вписанных в конкретные региональные условия, порождает экологические проблемы местного, регионального и глобального значения, которые, в свою очередь, нередко вызывают существенное социальное напряжение, ибо природопользование во всех случаях ведет к трансформации природно-ресурсного потенциала, в подавляющем большинстве случаев имеющей негативный характер. Если даже при этом возрастает продуктивность по тому или иному виду пользования, естественный облик природных ландшафтов изменяется, снижается биоразнообразие, уменьшается устойчивость экосистем, определяющих безопасное существование человека как биологического вида.

Эти проблемы обычно имеют конкретное местное или региональное значение, т. к. структура природопользования различна в различных районах.

Трансформация природно-ресурсного потенциала выражается в следующих формах:

1. На уровне конкретных, локальных ресурсных объектов некомплексное использование и загрязнение вызывают преждевременное исчерпание технологически доступной части ресурса и выведение из хозяйственного оборота всего объекта. При этом на объекте нередко остаются значительные объемы ресурса, недоступные лишь при применявшейся, нередко устаревшей технологии. Но в это время, как правило, уже известны технологии, позволяющие взять оставшийся ресурс. Обычно они впоследствии применяются, и происходят возвраты на объекты. Перерыв и каждый последующий возврат к освоению определенного ресурса требуют новых начальных вложений и часто наносят все более непоправимый урон природной среде.

Таких примеров много на ДВР. В горной промышленности - это двух- и трехкратные перемывания дражных отвалов с извлечением каждый раз новых объемов золота. В лесной промышленности - неполное использование запаса древесины при условно-сплошных и промышленно-выборочных рубках, что приводит к оставлению низкополнотных древостоев и последующим возвратам для новых рубок. Все эти повторные приемы (волны) освоения, как правило, создают каждый раз новые экологические проблемы и резко снижают возможность воспроизводства возобновимых ресурсов в целом.

Безусловно, встречается и практически полное исчерпание ресурса на объектах, которое приводит к закрытию предприятий и поселков, с чем в своем развитии столкнулись все регионы мира.

2. На уровне природно-ресурсного потенциала региона полное исчерпание ресурсов отдельных объектов, а также их условное (технологическое) исчерпание приводит к общему изменению объема и пространственной структуры 
этого потенциала. Освоение всех ресурсов начинается с наиболее транспортно доступных и качественно лучших объектов. Поэтому каждое полное или условное выбытие объекта превращает общий природно-ресурсный потенциал в более труднодоступный и, следовательно, требующий больших затрат на единицу использованного ресурса. Этой общей закономерности могут быть противопоставлены только новые технологии, а еще лучше - революционно новые методы, которые ведут: а) к снижению затрат на использование/добычу ресурса; б) к ресурсосбережению при использовании продуктов природопользования (что более важно).

Это касается всех ресурсных ситуаций, даже таких, когда выбывающие месторождения заменяются вновь открытыми, которые практически всегда находятся дальше от экономических центров, глубже в недрах или в морских толщах, выше в горах и т. д.

И для первого, и для второго уровня трансформации природно-ресурсного потенциала характерно не только изменение (как правило, сокращение) объема ресурса, но еще чаще - изменение его пространственной структуры, прежде всего существенная деконцентрация, которая и создает ситуацию, названую выше «условным исчерпанием».

В целом динамика природно-ресурсного потенциала региона может быть оценена только в пределах территориальных/акваториальных природно-ресурсных систем. При этом динамика каждого отдельного природного ресурса и природно-ресурсного потенциала в целом складывается из нескольких составляющих: естественных изменений (динамики лесов, колебаний речного стока и т. п.), добычи природного ресурса человеком (прямое ресурсопотребление), изменения природных ресурсов антропогенными воздействиями (обратное ресурсопотребление), изменений за счет той или иной связности природных ресурсов в территориальной системе. При этом может оцениваться как фактическое изменение природно-ресурсного потенциала за определенный прошедший период времени, так и прогнозируемая динамика, для чего можно использовать расчетный динамический природно-ресурсный баланс [1].

С точки зрения размещения природопользования в пространстве - его пространственной структуры - можно выделить несколько типов природопользования. Такая классификация должна строиться не для отдельных видов природопользования (хотя и это допустимо), а для совокупности всех видов пользования природными ресурсами в регионе. Нами выделены четыре типа, но классификация является открытой, и к ней могут быть добавлены другие типы и подтипы при их выявлении:

1. Поляризованная пространственная структура природопользования, при которой возникают два более или менее развитых, но не смыкающихся и не перекрывающихся объекта/ареала использования природных ресурсов. Это мо- 
гут быть объекты одного и того же вида природопользования, например две шахты в пустынной местности, не имеющей других видов природопользования, или не соприкасающиеся горнопромышленный ареал и аграрный оазис в той же пустынной или горно-таежной местности. Поляризованный тип пространственной структуры предполагает наличие в основном двух выраженных полюсов, но их может быть три и более, однако при большом количестве полюсов этот тип переходит в следующий тип - очаговый.

2. Очаговая пространственная структура природопользования, характеризующаяся тем, что ареалы воздействия объектов природопользования не смыкаются всплошную, а тем более не перекрываются. Возникает преимущественно в двух случаях:

1) в начальной стадии освоения неосвоенной территории/акватории;

2) в пользовании моноресурсными разрозненными объектами при отсутствии других видов природопользования.

Этот тип характерен для слабо освоенных районов, в зависимости от величины очагов он может быть разделен на три подтипа:

2.1. Точечное природопользование - наличие большего или меньшего множества незначительных пунктов освоения на неосвоенной в целом территории (отработка небольших россыпей и т. п.).

2.2. Ячеистое природопользование - точки освоения частично слились в очаги.

2.3. Линейно-ареальное природопользование - наличие ареалов освоения вокруг экономических центров, которые соединяются узкими освоенными полосами вдоль транспортных магистралей (рек, дорог и т. д.) при значительных неосвоенных межареальных пространствах.

3. Сплошная асимметричная пространственная структура природопользования формируется в условиях, когда вся территория/акватория освоена в той или иной степени, и все объекты/ареалы в той или иной степени смыкаются или перекрываются. Но в этом типе интенсивность природопользования в разных частях района различна. Как правило, развивается из предыдущих двух типов в ходе дальнейшего освоения. Может иметь несколько осей асимметрии.

Целесообразно выделить подтип:

3.1. Асимметричное природопользование с прибрежным морским поясом освоения. Как правило, такой пояс экономически более развит, чем остальная территория региона.

При больших пространственных размерах прибрежный морской пояс может быть выделен в отдельный подтип следующего типа.

4. Сплошная равномерная пространственная структура природопользования. В целом является результатом дальнейшего освоения и интенсификации использования природно-ресурсного потенциала. Возникает не всегда, т. к. размещение самого потенциала чаще всего неравномерное. 
Графически перечисленные типы следует изображать в виде трехмерных моделей, но для экономии места они показаны на рисунке 1 в виде профилей.

Эти типы приложимы к таксонам уровня района и выше. Более мелкие таксоны - урочища, а тем более биогеоценозы/элементарные экосистемы, как правило, полностью охватываются объектами природопользования, и выделять в них названные типы некорректно. Очевидно, что при оперировании типами размещения, особенно при их сравнении, необходимо работать с одинаковым уровнем таксонов.

Изложенные выше методологические позиции авторов исходят из их опыта изучения ДВР, для которого природопользование является ведущим сектором экономики, дающим треть ВРП региона, и который обеспечивает большую информацию для исследования проблем, поднимаемых в данной статье.

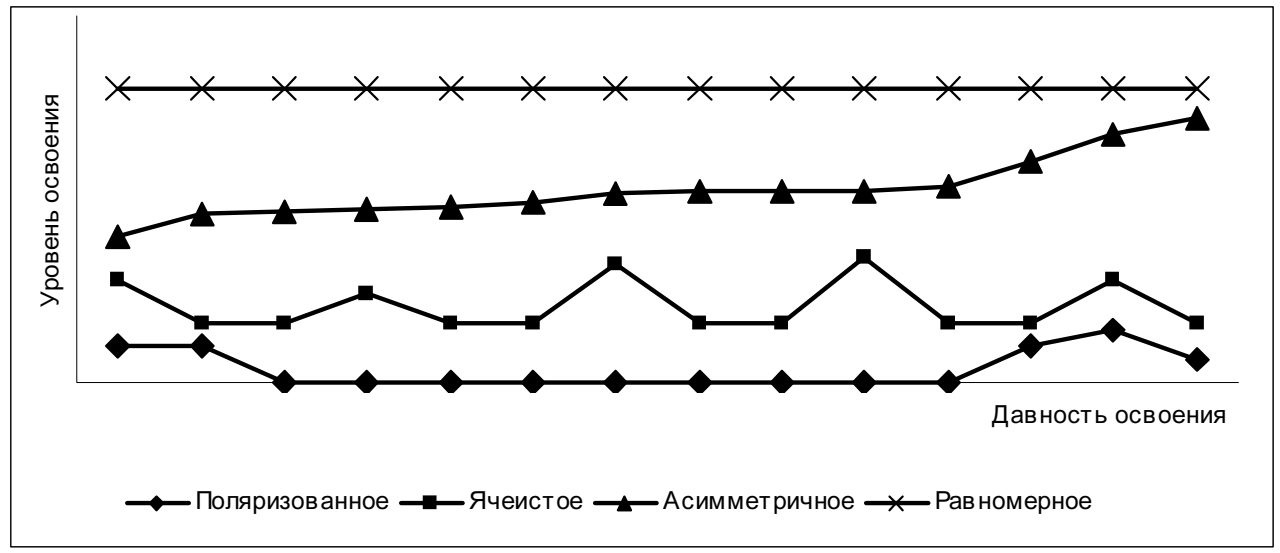

Рuc. 1. Профили территорий с разным типом размещения природопользования

Дальнему Востоку России присуща разнообразная территориальная структура природопользования, что проявляется в формировании на его обширных пространствах всех типов природопользования, приведенных выше в классификации, различных по степени интенсивности использования природных ресурсов и по территориальной представительности. Это обусловлено чрезвычайной пространственной дифференциацией естественно-географических условий, характером распределения природно-ресурсного потенциала, экономико-географическим (ЭГП) и геополитическим положением составляющих регион десяти субъектов Федерации.

О степени дифференциации естественно-географических условий региона можно судить хотя бы по тому, что здесь выделяются 38 крупных физикогеографических областей из 66, выделенных на всей территории России, относящихся к пяти ландшафтно-географическим зонам - арктическим пустыням, тундровой, лесотундровой, лесной и лесостепной [11]. Даже в пределах 
отдельных краев и областей, а тем более на обширной территории Республики Саха (Якутия), насчитывается от двух до десяти такого рода природных областей, значительно различающихся по условиям функционирования экономики и проживания людей. Кроме того, с ботанико-географической и агроклиматической точки зрения лесную зону, особенно на ДВР, принято разделять на зоны хвойных/таежных и хвойно-широколиственных лесов, а лесостепную зону правильнее рассматривать как прерие-лесную [6]. Не менее разнообразна природа омывающих ДВР водных пространств, относящихся к шести морям двух океанов.

Столь разнообразные и контрастные естественно-географические условия сказались на характере хозяйственной освоенности и интенсивности природопользования.

Генеральная закономерность в пространственном распределении типов природопользования на территории ДВР - расширение их спектра и пространственных масштабов при движении с северо-запада региона на юго-восток. Эти изменения в пространстве не являются плавными, а имеют несколько порогов, которые определены рядом природно-хозяйственных рубежей. Последние определяются:

- дифференциацией условий ведения товарного сельского хозяйства;

- дифференциацией условий товарного лесопользования, прежде всего пользования древесиной - лесозаготовок.

С природно-климатической точки зрения товарное земледелие возможно на территориях с суммой температур более $1800^{\circ} \mathrm{C}$, что включает прерие-лесную зону, зону кедрово-широколиственных лесов и подзону южной тайги.

Северная граница товарного древесинопользования тесно коррелирует с северной границей подзоны средней тайги.

В других физико-географических зонах и подзонах, имеющих более суровые природные условия жизнедеятельности и природопользования, т. е. в подзоне северной тайги, лесотундровой и тундровой зонах, а тем более в зоне полярных пустынь, спектр типов природопользования сужается, и остаются два блока:

- пространственно-емкое экстенсивное аборигенное природопользование - охота, оленеводство, собирательство, которые базируются на эксплуатации биопродуктивности громадных пространств; ${ }^{1}$

- очаговая и точечная по территориальной структуре эксплуатация уни-

${ }^{1}$ Сейчас природопользование коренных малочисленных народов официально получило неудачное наименование «традиционного». Следует ли в таком случае считать нетрадиционным существующее уже более полутораста лет на ДВР природопользование российских переселенцев, уходящее корнями в многовековое природопользование Европейской России, Урала и Сибири? Поэтому мы здесь и далее используем термин «аборигенное природопользование», который считаем более точным и понятным на международном уровне. Мы его распространяем на экономику не только малочисленных, но и не малочисленных коренных народов. 
кальных по запасам и/или типу ресурсов месторождений (якутские угли, золотые и платиновые месторождения севера Хабаровского края, нефть и т. д.).

В целом такую пространственную структуру природопользования ДВР можно отнести к асимметрично-сплошному типу, причем этот же тип повторяется почти во всех субъектах Федерации региона при их самостоятельном рассмотрении: слабее освоенный север и асимметричное наращивание освоенности природно-ресурсного потенциала к югу каждого субъекта РФ.

На столь громадном пространстве, как ДВР, на данную генеральную закономерность накладываются распределенные в пространстве на основании других закономерностей типы природопользования, связанные с:

- эксплуатацией биопродуктивности проходных рыб (морские/океанические побережья, часть рек);

- аборигенным природопользованием (например, очаг земледелия и животноводства в Центральной Якутии).

Неравномерность пространственной насыщенности территории природопользованием и значимости природопользования в экономике различных субъектов Федерации на ДВР представлена на рисунке 2 (субъекты Федерации расположены с севера на юг), который иллюстрирует:

- большой размах показателей, относящихся к субъектам Федерации, при сравнении со средним дальневосточным уровнем, отмеченным первым столбиком каждой из трех диаграмм;

- нарастание с севера на юг экономической освоенности территории, описанной плотностью населения, и освоения природно-ресурсного потенциала, выраженного плотностью ВРП, производимого природно-ресурсным сектором эКономики;

- иные, чем у первых двух показателей, пространственные соотношения доли природно-ресурсного сектора в ВРП территории. Последняя различна и структурно. Так, в Корякском автономном округе, который демонстрирует самую большую на ДВР зависимость своей экономики от природно-ресурсного сектора, основу составляет добыча рыбы. В Сахалинской области (2-й ранг по этому показателю) основу составляет сегодня добыча нефти и газа. В Республике Саха (Якутия) - добыча алмазов, хотя добыча топливно-энергетических ресурсов тоже вносит здесь значимую лепту.

Все три показателя, приведенные на рисунке 2, были проранжированы по субъектам Федерации, и вычислен коэффициент корреляции рангов Спирмена. Между плотностью населения и плотностью ВРП он оказался высоким $\left(\mathrm{R}_{\mathrm{sp}}=\right.$ 0,92) и достоверным при уровне существенности ошибки менее $2 \%$. Но даже при более мягком пороге существенности 5\% корреляция рангов между двумя другими парами показателей: доля сектора в ВРП территории с плотностью населения и с плотностью ВРП - оказалась недостоверной. 
Ппотность населения

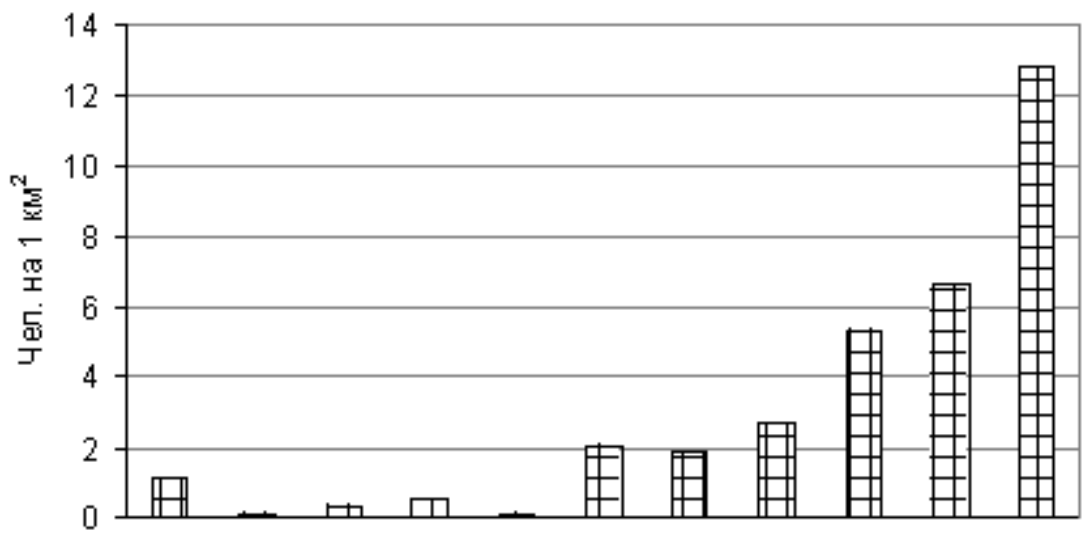

Плотность ВРП

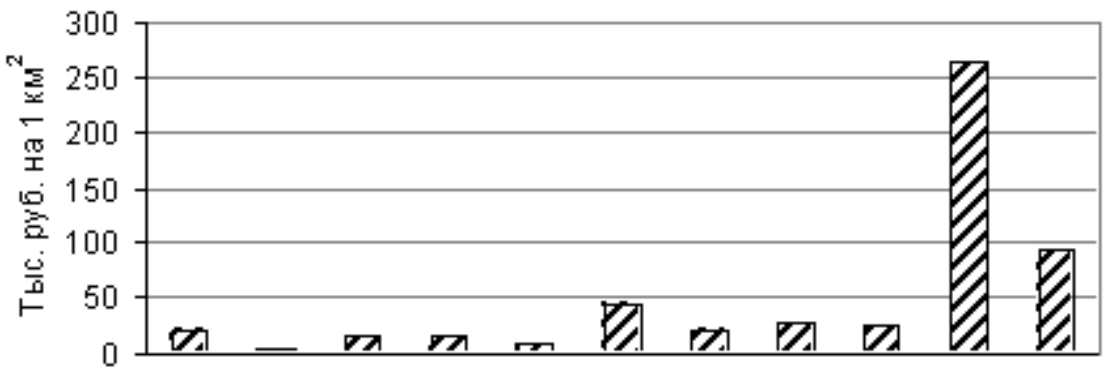

Доля продукции природно-ресурсного сектора в ВРП

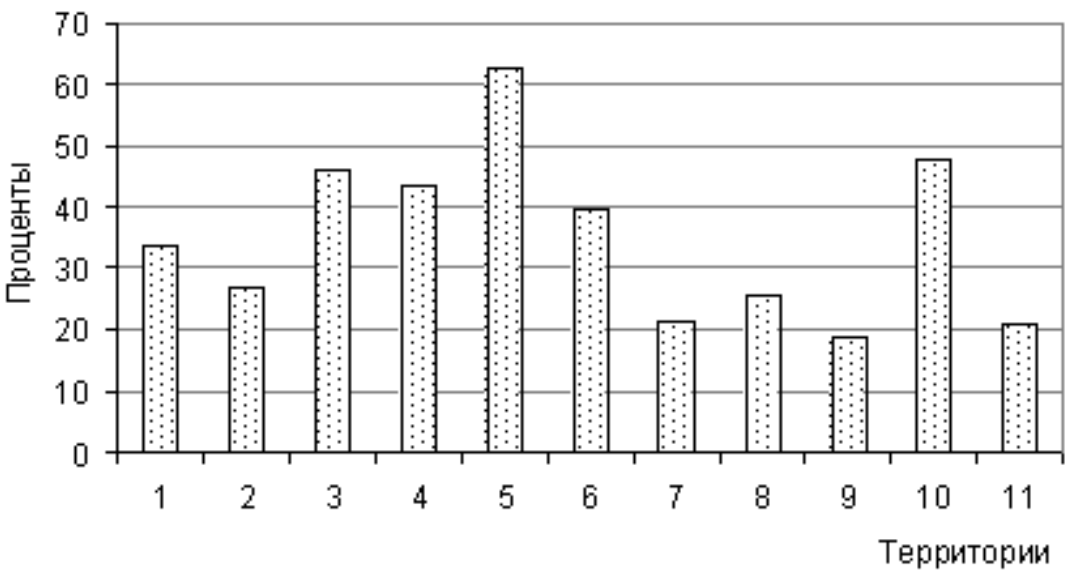

Pис. 2. Удельные показатели природопользования по субъектам Федерации на ДВР, 2001 г.:

1 - ДВР; 2 - Чукотский автономный округ; 3 - Республика Саха (Якутия);

4 - Магаданская область; 5 - Корякский автономный округ; 6 - Камчатская область;

7 - Хабаровский край; 8 - Амурская область; 9 - Еврейская автономная область; 10 - Сахалинская область; 11 - Приморский край 
Пространственная дифференциация структуры природопользования в укрупненном масштабе вписывается в экономическо-административное деление и экономическое районирование ДВР. Это объясняется, в первую очередь, тем, что большая часть административных границ субъектов РФ в регионе и соответственно опирающееся на них экономическое районирование базируются на природных и природно-хозяйственных рубежах.

В рамках Российской Федерации ДВР выделяется как единый экономический район, совпадающий ныне с Дальневосточным федеральным округом. Дальневосточный экономический район, исходя из характера разделения труда, содержания основных народнохозяйственных проблем, структуры экономик, их взаимодополняемости и способов встраивания их в экономическое пространство региона, наконец, учитывая территориальную общность, можно разделить на три макроэкономических района в следующем составе (рис. 3, табл. 1):

- Северо-Западный - Республика Саха (Якутия);

- Северо-Восточный - Камчатская и Магаданская области, Корякский и Чукотский автономные округа;

- Южный - Приморский и Хабаровский края, Амурская, Сахалинская ${ }^{1}$ и Еврейская автономная области [12].

Относительно развитая структура природопользования представлена только в Южном макрорайоне. Этот макрорайон, занимая 23,2\% площади ДВР, концентрирует 76,9\% населения региона, практически все товарное земледелие (93,3\% посевных площадей), 96,4\% товарных лесозаготовок и многое другое. В связи с этим пространственное распределение природопользования в этом макрорайоне заслуживает более подробного рассмотрения.

Юг ДВР, как и весь регион, также внутренне неоднороден. Это природнохозяйственный макрорайон с площадью 1,4 млн км² (1\% суши земного шара), который обладает специфическим набором проблем природопользования. Это важнейшая территория Азиатской России по перспективам социально-экономического развития и проблемам сохранения окружающей природной среды, в том числе биоразнообразия.

По плотности, концентрации и динамике численности населения, типу хозяйственного освоения территории и природным условиям жизни и деятельности Юг ДВР делится на три широтные и одну островную природно-хозяйственные зоны освоенности: Северную, Центральную, Южную и Восточную.

Эти зоны в меньшем масштабе повторяют общедальневосточную законо-

${ }^{1}$ В связи с четко обозначившейся за последние годы ресурсно-хозяйственной спецификой природопользования Сахалинской области в дальнейшем, видимо, станет целесообразным выделение ее и прилегающего шельфа в качестве самостоятельного Япономорского макроэкономического района. 
мерность территориальной дифференциации природопользования и условий хозяйствования. Формирование зон определено многими факторами, но базовыми являются два: теплообеспеченность и транспортная доступность.

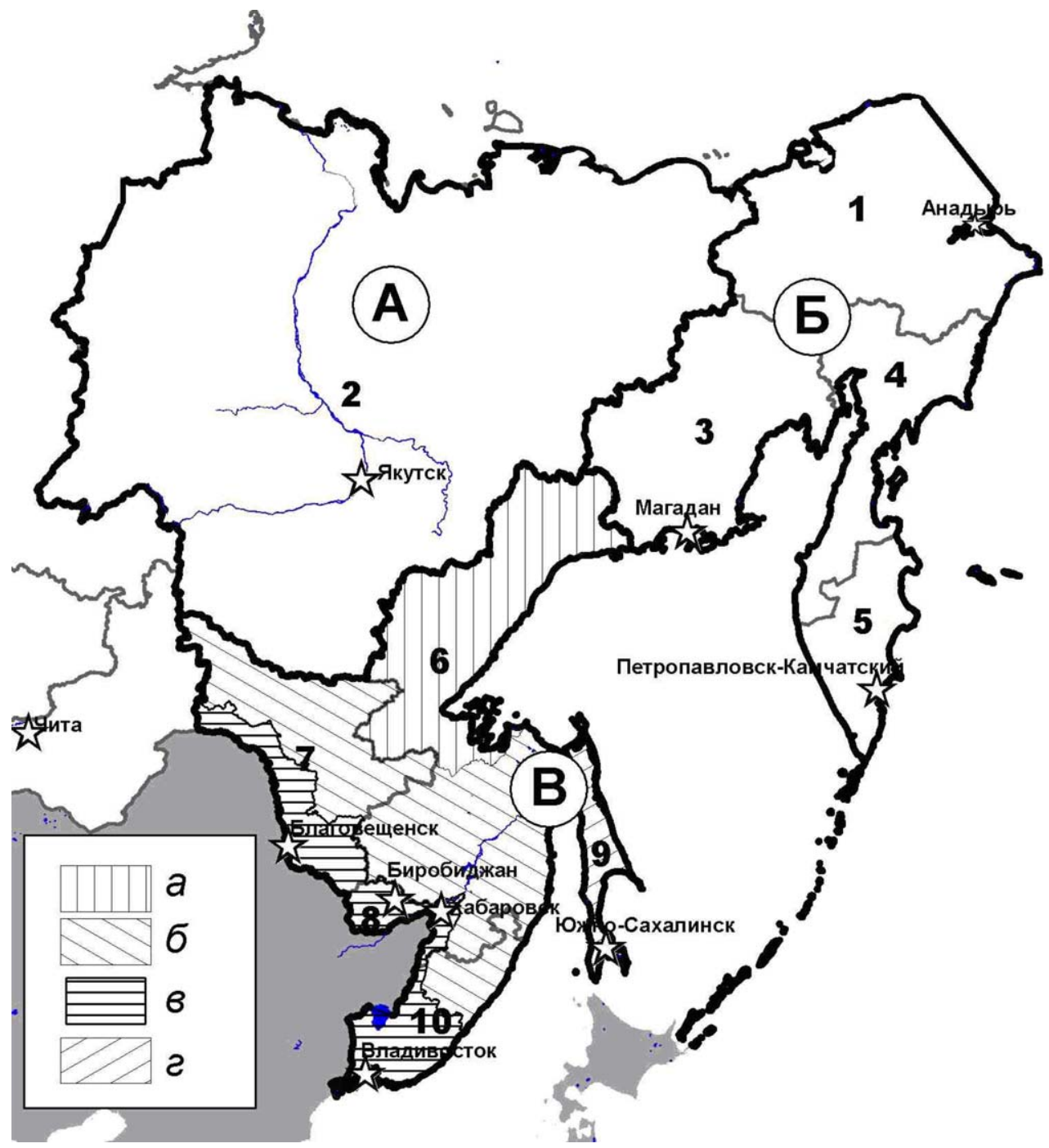

Источник: [12].

Рис. 3. Макроэкономическое районирование Дальнего Востока России: макроэкономические районы: А - Северо-Западный, Б - Северо-Восточный, В - Южный; зоны Южного макроэкономического района: а - Северная, б - Центральная, в - Южная, г - Восточная;

субъекты Федерации: 1 - Чукотский автономный округ, 2 - Республика Саха (Якутия),

3 - Магаданская область, 4 - Корякский автономный округ, 5 - Камчатская область,

6 - Хабаровский край, 7 - Амурская область, 8 - Еврейская автономная область, 9 - Сахалинская область, 10 - Приморский край. 
Транспортная доступность ареалов изначально определялась их расположением относительно основной транспортной магистрали России и Юга ДВР Транссиба. Для Юга ДВР второй по значимости и первой по времени освоения является также транспортная магистраль Амура с его притоками. С конца 1970-х гг. возникла еще одна важная межрегиональная магистраль, проходящая по северу Южного макрорайона, - Байкало-Амурская железная дорога (БАМ).

Таблица 1

Макроэкономические показатели экономических районов ДВР

\begin{tabular}{|c|c|c|c|c|c|c|c|}
\hline \multirow{2}{*}{ Таксон } & \multicolumn{2}{|c|}{ Площадь, 2003 г. } & \multicolumn{2}{|c|}{$\begin{array}{c}\text { Население, } \\
\text { перепись } 2002 \text { г. }\end{array}$} & \multirow{2}{*}{$\begin{array}{c}\text { Плотность } \\
\text { населения, } \\
\text { чел./км² }\end{array}$} & \multirow{2}{*}{$\begin{array}{c}\text { ВРП, } \\
\text { млрд } \\
\text { руб., } \\
2001 \text { г. }\end{array}$} & \multirow{2}{*}{$\begin{array}{c}\text { Число } \\
\text { городов, } \\
2002 \text { г. }\end{array}$} \\
\hline & $\begin{array}{l}\text { тыс. } \\
\text { кM }^{2}\end{array}$ & $\%$ & $\begin{array}{l}\text { тыс. } \\
\text { чел. }\end{array}$ & $\%$ & & & \\
\hline \multicolumn{8}{|l|}{ Макрорайоны: } \\
\hline Северо-Западный & 3103,2 & 49,9 & 949 & 14,2 & 0,3 & 100,0 & 13 \\
\hline Северо-Восточный & 1671,4 & 26,9 & 596 & 8,9 & 0,4 & 46,3 & 9 \\
\hline Южный & 1441,3 & 23,2 & 5148 & 76,9 & 3,6 & 247,4 & 48 \\
\hline \multicolumn{8}{|c|}{ в т. ч. зоны Южсного макрорайона: } \\
\hline Северная & 423,3 & 6,8 & 19 & 0,3 & 0,04 & & - \\
\hline Центральная & 658,9 & 10,6 & 854 & 12,8 & 1,3 & & 6 \\
\hline Южная & 272 & 4,4 & 3728 & 55,7 & 13,7 & & 24 \\
\hline Восточная & 87,1 & 1,4 & 547 & 8,2 & 6,3 & 48,1 & 18 \\
\hline ДВР & 6215,9 & 100, & 6693 & 100 & 1,1 & 393,7 & 70 \\
\hline
\end{tabular}

Источники: [10] и расчеты авторов, 2004.

Дифференциация теплообеспеченности определяет в пределах рассматриваемой территории смену трех ботанико-географических зон, названных выше, а следовательно условия деятельности таких важнейших экономических комплексов, как аграрно-промышленный (АПК) и лесопромышленный (ЛПК).

Каждая из экономических зон Южного макроэкономического района обладает специфическим набором проблем природопользования. Различие социально-экономических и природно-хозяйственных условий в пределах зон требует разработки для каждой из них собственной политики природопользования.

Социально-экономическое развитие Северной зоны связано с точечным использованием уникальных, мирового класса месторождений, ряда биоресурсов прибрежной зоны и поддержанием жизнедеятельности коренного населения. Такой характер природопользования, структуры освоенности и хозяйственной активности, видимо, сохранится в долгосрочной перспективе. 
Возможности социально-экономического развития Центральной зоны, а соответственно и природопользования, в значительной мере определяются позицией государства. История XX в. показала, что только при создании государством того или иного льготного режима происходит полномасштабное развитие этой зоны. Прекращение преференций приводит к оттоку населения и развалу социально-экономического комплекса, возврату к обычному таежному природопользованию. Наиболее наглядным примером прохождения всех этапов является история строительства БАМа от 1930-х гг. до наших дней. Исключение из этого правила составляет точечное освоение уникальных сырьевых объектов, ценность продукции которых позволяет достичь самообеспечения без специальной государственной поддержки.

Таким образом, это наиболее поливариантная по возможностям социальноэколого-экономического развития часть Юга ДВР. Однако из этого множества вариантов выделяются два основных направления экономического развития зоны, которые могут сочетаться:

- Использование природных ресурсов как основы местной экономики. При этом варианте наиболее важным фактором пространственного освоения территории и возникновения проблем природопользования является использование лесных ресурсов, которые перекрывают всю территорию зоны. Здесь сосредоточена основная коммерчески доступная часть таежных лесов и северной фации хвойно-широколиственных лесов.

- Транспортный транзит, развитие которого в большой степени существует в потенции и в значительной мере зависит от внешнеполитической ситуации.

С точки зрения и социально-экологической, и экономической устойчивости, критическим моментом является выбор схемы территориальной организации природопользования, будет ли это:

- сплошным освоением с ориентацией на долгосрочное использование комплекса ресурсов и поддержкой постоянства населения на базе создания разветвленной сети населенных пунктов;

- ячеистым/очаговым освоением с использованием большей части природных ресурсов на основе временных вахтовых поселков и формированием в качестве постоянных только опорно-тыловых баз, возможно за пределами зоны.

Выбор рациональной политики природопользования для данной зоны жестко связан с определением государством своих преференций.

Развитие Южной зоны определяется в значительной мере ее внутренним потенциалом, наиболее богатым на территории ДВР, который включает высокий агропотенциал, полидоминантные хвойно-широколиственные леса, широкий набор других природных ресурсов, трудовые ресурсы, накопленную инфраструктуру, выгодное экономико-географическое положение и т. д. 
История освоения севера Тихоокеанского кольца демонстрирует противоположные типы развития опорно-тыловых баз. Близкое по типу освоение золотоносных полей Колымы на ДВР и Юкона на Аляске опиралось на прибрежные тыловые базы, в первом случае - Владивосток, Находка, Ванино, во втором - Сан-Франциско, Сиэтл, Ванкувер. Три североамериканские базы, используя ситуацию, обогатились и в дальнейшем превратились в развитые экономические, а затем и социально-культурные центры. Для дальневосточных городов-портов их использование в качестве тыловых баз эксплуатации богатейших месторождений драгоценных металлов не принесло существенного и устойчивого процветания. В этом различии сказалось, прежде всего, различие политико-экономических основ, а, следовательно, и разных подходов к освоению.

Социально-экономическое развитие этой части Юга ДВР может продолжаться вне зависимости от государственной политики. Государственная политика может только ускорить или замедлить процесс, направленность которого однозначно сложилась. Однако именно государственная политика определяет, в каких пределах будет реализована большая часть существующих на сегодня для Юга ДВР сценариев экономического развития.

Структура природно-ресурсного потенциала этой зоны создает хорошую базу для перехода к устойчивому природопользованию, которое необходимо и потому, что эта зона территориально совпадает с особым экологическим регионом мира, где сосредоточена не только большая часть ресурсно-экономических потенций юга ДВР, но и высокий уровень биоразнообразия с проблемами его сохранения. Например, именно к этому пространству привязаны такие проблемы мирового ранга, как сохранение амурского тигра, дальневосточного леопарда и др. [13].

Развитие Восточной зоны будет определяться тем, что использование месторождений нефтегазового бассейна в обозримой перспективе не только подчинит себе другие виды природопользования, но и определит всю социально-экологоэкономическую обстановку. Этот вид пользования в основном сосредотачивается на шельфовой части акватории зоны, но он изменит, как минимум, значительную долю территории острова Сахалин, прежде всего, его побережья. В то же время природная среда острова очень хрупкая, и здесь экономическое развитие требует особых мер. Возникающие при этом проблемы, так же как и пути их решения, хорошо известны из истории развития соседнего района Японии Хоккайдо, находящегося в аналогичных природных условиях.

Анализ динамики границ природно-хозяйственных зон Юга ДВР в XX в. показал, что эти зоны являются устойчивыми территориальными образованиями, проявившими свою специфику при всех волнах освоения ушедшего века $[3 ; 4]$. 
В то же время указанный выше мобильный характер природопользования в пространстве проявляется в непрерывном, хотя и достаточно постепенном перераспределении между экономическими макрорайонами и составляющими их зонами реального использования природно-ресурсного потенциала. В связи со снятием политических ограничений на взаимодействие отечественной экономики с международной, особенно мощное воздействие стало оказывать на пространственную трансформацию природопользования ДВР его усиливающаяся интеграция с экономикой Азиатско-Тихоокеанского региона, прежде всего, Северо-Восточной Азии - СВА [8]. Это воздействие усиливается во времени, т. к. роль ДВР как одного из важнейших природно-ресурных регионов СВА в связи с быстрым ростом экономики этого мегарегиона мира возрастает. Последнее придает природопользованию ДВР значительный геополитический смысл в этом насыщенном геополитическими проблемами мегарегионе.

Таким образом, проблема изучения пространственных аспектов природопользования является важной научной задачей, решение которой создает научное обеспечение перехода региона к устойчивому природопользованию, а тем самым - к устойчивому развитию ДВР. Эта проблема имеет достаточно длительную историю исследований, которая отразилась в большом количестве научных публикаций по различным смежным дисциплинам. Однако можно говорить, что в целом эти исследования пока не носили достаточно системного, целенаправленного характера, особенно в области междисциплинарных разработок. Ограниченный формат журнальной статьи не позволяет авторам дать полный обзор проблемы и стоящих задач дальнейших исследований. Но, безусловно, целесообразно такие исследования в рамках ДВР интенсифицировать. Целесообразно на этом этапе создать научно-общественный координирующий орган в виде совместной комиссии двух объединенных научных советов ДВО РАН - общественных наук и наук о Земле.

\section{СПИСОК ЛИТЕРАТУРЫ}

1. Бакланов П. Я. Динамика природно-ресурсного потенциала территории и методы ее оценки // География и природные ресурсы. 2000. № 3. С. 10-16.

2. Бакланов П. Я. Дальневосточный регион России: проблемы и предпосылки устойчивого развития. Владивосток: Дальнаука, 2001.

3. Вишневский Д. С., Каракин В. П. Природно-хозяйственное зонирование юга ДВР как основа регионализации политики природопользования // Перспективы развития российских регионов: Дальний Восток и Забайкалье до 2010 года: Мат. междунар. науч.-практ. конф. Хабаровск: Ин-т экон. исследований, 2001. С. 296-301.

4. Каракин В. П. Экономико-географическое положение СВА как условие интеграционных процессов // Дальний Восток России: плюсы и минусы экономической интеграции. Мат. междунар. науч. конф. Хабаровск: Ин-т экон. исследований ДВО РАН, 2004. C. 133-138.

5. Каракин В. П., Шейнгауз А. С. К новому природопользованию // Экологическая альтернатива. М.: Прогресс, 1990. С. 636-659. 

1955.

6. Колесников Б. П. Очерк растительности Дальнего Востока. Хабаровск: Кн. изд-во,

7. Природопользование Российского Дальнего Востока и Северо-Восточная Азия / Под ред. А.С. Шейнгауза. Хабаровск: РИОТИП, 1997.

8. Пространственные трансформации в российской экономике / Под ред. П. А. Минакира. М.: ЗАО «Экономика», 2002.

9. Региональное природопользование: методы изучения, оценки, управления. Учебное пособие / Под ред. П. Я. Бакланова и В. П. Каракина. М.: Логос, 2002.

10. Регионы России. Социально-экономические показатели, 2003: Стат. сб. в 2 т. / Госкомстат России. М., 2003. Т. 1, 2.

11. Физико-географическое районирование СССР. Характеристика региональных единиц / Под ред. Н.А. Гвоздецкого. М.: МГУ, 1968.

12. Экономическая политика: региональное измерение / Под ред. П. А. Минакира. Владивосток: Дальнаука, 2001.

13. Newell, Josh. The Russian Far East. A Reference Guide for Concervation and Development. McKinleyville (CA, USA): D\&D Publishers, 2004.

14. Tietenberg, Tom. Environmental and Natural Resource Economics. 3rd edition. NY: HarperCollins Publishers Inc., 1992. 